\title{
Development of a Behavioral Counseling Services Model Using Assertive Training Techniques Through Role-Playing Game to Improve Assertive Behavior of Bullying Victims
}

\begin{abstract}
Romika Rahayu*, Masdi Janiarli and Mi rajul Rifqi
Social Science Education, Pasir Pengaraian University, Riau

*Corresponding author. Email: romikarahayu91@gmail.com

ABSTRACT

Indonesian children have been being victims of bullying in schools; they have physical and mental health problems. Being a victim of bullying starts from often displaying low assertive behavior. This is one of the many causes of bullying. The research objective is to develop a counseling model that is able to improve the assertive behavior of bullying victims. The research method used is Research and Development, the determination of the sample using purposive sampling, using assertive behavior scale instruments. Based on the results of product trials through experimental research, which is to provide behavioral counseling services with assertive training techniques through role-playing games, this counseling service is proven to increase assertive behavior in victims of bullying. This can be seen before given counseling services (pretest) and after given counseling services (post-test), supported by the results of the difference test, it can be seen from an exact Sig (2-tailed) of 0.004, which means $<2.178$. This indicates that the developed behavioral counseling model with assertive training techniques through role-playing games is evidently effective in increasing the assertive behavior of bullying victims.
\end{abstract}

Keywords: Behavioral counseling, assertive behavior, assertive training, bullying victims.

\section{INTRODUCTION}

This research is based on several things; first, the world of education has become a hotbed of growing bullying. Indonesian Child Protection Commission data in 2016 stated that Indonesia is under caution in cases of bullying and continues to experience approximately $100 \%$ reduction from the previous year. It was then noted in 2018 (tempo.co.id) that nearly 50\% of children experienced physical violence in school, observable rates of bullying cases each year did not show a significant decrease. Of course, this indicates that the school's efforts in eradicating Bullying, Child Protection laws No. 23 of 2002 article 54 states that "students who are in the school environment and during education should be obliged to be protected from various acts of violence by teachers, school managers or friends in the school.

Second, according to Simons \& Mawn [1], children who are victims of bullying are likely to become perpetrators of bullying, because the act of bullying is allowed to become legal then this behavior will become a learning resource in other individuals, such as juniors or peers, then become collective behavior, which is a spontaneous and unstructured behavior that develops in an individual or group [1]. If this is not considered seriously, it will have a huge impact on our country's human resources. Zakiyah [2] suggests that children who are victims of bullying are at risk of various health, physical and mental problems, lose appetite, decrease learning achievement, be reluctant to go to school, or lose motivation to school. Then, victims of bullying tend to take revenge. This is in line with Susilowati [3], who states that bullying victims show more aggressive and more impulsive traits.

Based on the results of interviews with the teachers, They stated that bullying has often been found in the school. Added to this, couseling activity has not been seemingly effective in solving the school bullying problems. In fact, the safety of students in schools is a shared responsibility, and this has been regulated by Child Protection Laws (UUPA) No. 23 of 2002 article 
54. The regulation states that, "students who are in a school environment and during education are required to be protected from various acts of violence committed by teachers, school managers or friends in the school, or other educational institutions."

From some of the above findings, this research is important to implement to produce effective guidance in dealing with the school bullying victims. One of the approaches that can be employed to eradicate bullying is psychological approach. This can be achieved using group counseling services through behavioral counseling using assertive training techniques. This has been proven through several research results, including assertive exercises that can help students in understanding the concept of assertive behavior and how to apply it in daily life [4], then Hermalinda [5] found that assertive skill training could prevent teenagers from bullying behavior. Looking back at the results of existing research, among others, Karyanti [6] found that using ssertive training techniques were able to improve assertive behavior in victims of bullying. In this respect, Azis [7] claims that using assertive training were able to improve assertive behavior of bullying victims. In addition, Rogamelia and Risna [8] found that assertive behavior in victims of bullying can be improved through SPICC model counseling. This model is effective for improving assertive behavior in bullying victims.

Basically, behavioral counseling attaches the counseling process to learning theory. The concept of behavior is about behavior change obtained through the learning process, through the process of interaction with the environment through the laws of learning, such as habituation and imitation, meaning that in this counseling process there will be a learning process of new behavior in exchange for old behaviors that are not adaptive to adaptive, this is developed or adopted in the counseling group, some mention the definition of behavioral counseling which states that behavioral counseling is the process of elimination of maladaptive learning outcomes and the provision of learning experiences in which it contains appropriate and unlearned responses [8]. It is in line with the purpose of behavioral counseling which is to reflect the problem of counseling; as a direction in the implementation of counseling; as a basis in determining counseling strategies; and as a frame of reference in evaluating the results of counseling. Behavioral counseling services developed with several more techniques in the concept of behavioral is through assertive exercise, which is specifically designed to help individuals who are unable to express their feelings such as angry, or offended, display excessive politeness behavior and always encourage others to step over it, difficult to resist or say no, difficult to express affection or positive response, feel unable to do what to be its rights and responsibility [8][9].
Understanding the purpose and workings of behavioral counseling, researchers assume that victims of bullying who have high assertive behaviour can be the solution to solve the schools bullying problems. It is evident that students who experience bullying are students who have low levels of assertive [9]. The low assertive students are not able to express their own feelings such as anger, offending, and other weak behaviors that show themselves weak in the presence of bullying perpetrators. This is because there is a low relationship between being a victim of bullying. This is reinforced by some research results one of them, Novalia and Dayakisni [10], there is a very significant negative relationship between assertive behavior and the tendency to be a victim of bullying in students. After studying behavioral counseling and looking at the condition, the researchers considered this one of the broad enough steps that can be taken to stop bullying behavior in schools, namely by improving assertive behavior in victims of bullying.

After investigating the objectives, assumptions, behavioral counseling ways of work, theories, and results of previous research, researcher assume that assertive behavior in bullying victims can be improved using assertive behavior training techniques through role-playing games. In line with the behavioral view, human behavior is the result of learning, and can be changed through the conditioning of certain behaviors through assertive training. Participants were trained to express feelings of offending: difficulty to express rejection; and expressing affection, and other positive responses. Anggraini [11] claims that behavioral counseling services are effective to increase assertive behavior in students.

Based on the library review description above, the researchers decided the above description becomes the basis of thinking in the development process towards group counseling in schools. Producing a new concept in counseling services in schools is specifically formulated to improve assertive behavior in victims of bullying in schools. The purpose of this study is to develop behavioral counseling services by using assertive training techniques through effective roleplaying games to improve assertive behavior in victims of bullying.

\section{RESEARCH METHODS}

The research was conducted as counseling services at public vocational high school (SMKN) 2 Rambah. This reasearch employed research and development (R\&D) method which developed a behavioural counseling services using assertive training using roleplaying games. Borg and Gall [12] state that the R\&D method is "a process used to develop and validate educational products[12]. The steps in the Borg and Gall [12] R\&D's model are preliminary studies; planning; 
hypothetical model development; hypothetical model review; revision; limited trials; revised trial results; broader trials; final model revisions; and dissemination and socialization. However, this study was terminated at the stage of limited try-out as can be seen in the following flowchart.

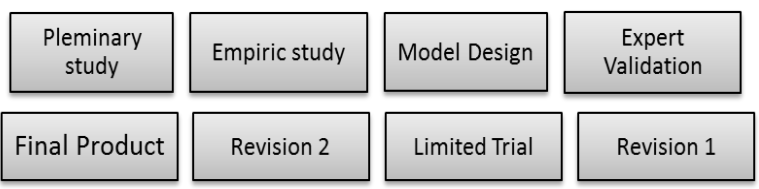

Figure 1 Research Flowchart

Through research and development methods, researchers can use it to produce certain products andtest the effectiveness of the development results [13]. An experimental test was conducted to find out the limited effectiveness test.

The Experimental test was conducted by researchers using the design of one pretest and post test group. In

\section{RESULTS AND DISCUSSION}

The researcher cariied out the development of counseling in the field through several stages of research and development method. It started from conducting theoretical and empirical studies, developing the model, then experts and practitioners validation. The result is a hypothetical model including: 1) Background;, 2) Basic assumption; 3) Basic concept; 4) implementation of counseling (work procedures, counselor competencies, and policy administrators); and 5) evaluation and follow-up.

The research findings show that there is increasing of post-test scores after using the behavioural counseling services model using assertive training techniques through role-playing games compared to pretest scores. The t-test was measured using SPSS 16 which is demonstrated on Table 1 .

Based on table 1, it highlights that the sig (2 tailed) value is $0.00<0.05$, this indicates that there is a change in the average assertive behavior of bullying victims

Table 1. Result of t-test (pre-test and post-test)

\begin{tabular}{|c|c|c|c|c|c|c|c|c|c|}
\hline & \multicolumn{5}{|c|}{ Paired Differences } & \multirow{3}{*}{$\mathrm{T}$} & \multirow{3}{*}{$\mathrm{df}$} & \multirow{3}{*}{ Sig. (2-tailed) } \\
\hline & & \multirow[t]{2}{*}{ Mean } & \multirow[t]{2}{*}{ Std. Deviation } & \multirow{2}{*}{$\begin{array}{l}\text { Std. Error } \\
\text { Mean }\end{array}$} & \multicolumn{2}{|c|}{$\begin{array}{l}\text { 95\% Confidence Interval } \\
\text { of the Difference }\end{array}$} & & & \\
\hline & & & & & Lower & Upper & & & \\
\hline Pair 1 & $\begin{array}{c}\text { Before- } \\
\text { After }\end{array}$ & -5.000 & 2.000 & .707 & -6.672 & -3.328 & -7.071 & 7 & .000 \\
\hline
\end{tabular}

doing so, the researchers compared the pretest versus the post-test results. In this research, the design was given only to one group without any comparison group. The research subjects were students of XI grade which were selected trhough purposive sampling. The eight students selected in this limited trial were students who had low assertive behavior scores.

To collect data in this study, researchers used various instruments developed in various forms, 1) assertive behavior scale to assess student's assertive behavior, 2) interview guidelines to reveal the implementation of counseling services in dealing with bullying in schools, 3) validation instruments to assess construction model, the quality aspects of the model guide. The aspects measured in assertive behavior are aspects, 1) able to express positive feelings, 2) selfaffirmation, and 3) able to express negative opinions.

The mean scores difference test (t-test) between the pre-test and post-test results was used to determine the effectiveness of the developed model in elevating students' assertive behaviour. The researchers then compared the pre-test and post-test scores to examine the improvements occur after implementing the model [14]. before and aftergiven behavioral counseling services with assertive training techniques through role-playing games. This shows that the counseling services model developed is effectively increase assertive behavior among victims of bullying.

Table 2. Test of Normality

\begin{tabular}{|c|c|c|c|c|c|c|}
\hline \multirow{2}{*}{} & \multicolumn{3}{|c|}{$\begin{array}{c}\text { Kolmogorov- } \\
\text { Smirnova }\end{array}$} & \multicolumn{3}{c|}{ Shapiro-Wilk } \\
\cline { 2 - 7 } & Statistic & df & Sig. & Statistic & df & Sig. \\
\hline Before &, 201 & 8 &, $200^{*}$ &, 954 & 8 &, 752 \\
\hline After &, 254 & 8 &, 138 &, 867 & 8 &, 140 \\
\hline
\end{tabular}

The data normality test was performed using the Kolmogorov Smirnov test using SPSS 16. The test showed a significant value of $0.200>5 \%$. It indicates that the pre-test data were normally distributed. The post-test Kolmogorov Smirnov normality test is higher than the significant value of $0.138>5 \%$, so $\mathrm{H} 0$ is accepted. This means that the post-test data is normally distributed.

The success in conducting this research is closely related to the participants' involvement. The researchers then prioritized assertive training techniques, which are exercises to get used to displaying assertive behavior in interacting with those around the students. This is also supported by the findings of Keliat [15]. The 
conclusions of the results of this study indicate that assertive training has an added value effect for bullying prevention programs. Assertive training is effective in providing knowledge and assertive behavior among adolescents. This is supported by researchers using roleplaying games, where participants play games that can form assertive training for participants. Bowman [16] reinforces the use of role-playing games by mentioning that role playing games are very helpful for social problems or conflicts in groups, and one of the social conflicts in the group is bulyying.

\section{CONCLUSIONS}

Counseling services at public vocational high school (SMKN) 2 Rambah have been implemented. In fact, there has never been any development of counseling services specifically to increase assertive behavior of bullying victims. The developed counseling services model consists of 1) background, 2) basic assumptions, 3) basic concepts, 4) implementation of counseling (work procedures, councelor competencies, and policy administrators), 5) evaluation and follow-up. In summary, the results of the development of counceling services at the research field using assertive training techniques through role playing games are evidently effective in increasing the assertive behavior of bullying victims.

\section{REFERENCES}

[1] S. R. Simons and B. Mawn, Bullying in the Workplace-A Qualitative Study of Newly Licensed Registered Nurses, $A A O H N$ J., vol. 58, no. 7, pp. 305-311, 2010.

[2] E. Z. Zakiyah, S. Humaedi, and M. B. Santoso, Faktor Yang Mempengaruhi Remaja Dalam Melakukan Bullying, Pros. Penelit. dan Pengabdi. Kpd. Masy., vol. 4, no. 2, pp. 324-330, 2017.

[3] Susilowati, Profil Kepribadian 16 Pf Pada Siswa Korban Bullying, Universitas Muhammadiyah Surakarta, 2011.

[4] M. Paeezy, M. Shahraray, and B. Abdi, Investigating the impact of assertiveness training on assertiveness, subjective well-being and academic achievement of Iranian female secondary students, Procedia - Soc. Behav. Sci., vol. 5, no. 2, pp. 1447-1450, 2010.
[5] H. Herman, D. Nurshal, and D. Novrianda, The Effect of Assertive Training on Bullying in Junior High School, J. Keperawatan Soedirman, vol. 15, no. $1,2020$.

[6] Karyanti, A. Atmoko, and I. Hitipeuw, Keefektifan pelatihan keterampilan asertif untuk meningkatkan perilaku asertif siswa korban bullying di SMA, $J$. Pendidik. Hum., vol. 3, no. 2, pp. 116-121, 2015.

[7] A. R. Aziz, Efektivitas Pelatihan Asertivitas untuk Meningkatkan Perilaku Asertif Siswa Korban Bullying, J. Konseling dan Pendidik., vol. 3, no. 2, pp. 8-14, 2015.

[8] R. Rogamelia, Efektivitas Penggunaan Konseling Model Sequentially Planned Integrative Counseling For Children (Spicc) Untuk Meningkatkan Perilaku Asertif Korban Bullying (Stusi Eksperimen Kuasi Pada Siswa Kelas IV SD Negeri 1 Kelapa Tujuh Lampung Utara Tahun Pelajaran, Universitas Pendidikan Indonesia, 2014.

[9] D. Soendjojo, Mengajarkan Asertifitas Pada Remaja, J. Psikol., vol. 4, no. 3, pp. 5-7, 2009.

[10] Novalia and T. Dayaksini, Perilaku Asertif dan Kecenderungan Menjadi Korban Bullying, J. Ilm. Psikol. Terap., vol. 01, no. 01, pp. 172-178, 2013.

[11] I. Anggraeni, Efektivitas Konseling Kelompok Dengan Teknik Assertive Training Untuk Meningkatkan Harga Diri (Self Esteem) Peserta Didik Kelas X Di Sma Negeri 6 Bandar Lampung Tahun 2017/2018, Universitas Islam Negeri Raden Intan, 2017.

[12] W. R. Borg, J. P. Gall, and M. D. Gall, Educational Research: An Introduction, 8th ed., New York: Allyn and Bacon Inc, 2007.

[13] Sugiyono, Metode Penelitian Administrasi. Bandung: CV. Alfabeta, 2010.

[14] Sugiyono, Metode Penelitian Pendidikan, Pendekatan Kuantitatif, Kualitatif dan $R \& D$. Bandung: CV. Alfabeta, 2009.

[15] B. A. Keliat, T. A. Tololiu, N. H. C. Daulima, and E. Erawati, Effectiveness Assertive Training of Bullying Prevention among Adolescents in West Java Indonesia, Int. J. Nurs., vol. 2, no. 1, pp. 128$134,2015$.

[16] S. L. Bowman, Social Conflict in Role-Playing Communities: An Exploratory Qualitative Study, Int. J. Role-Playing, vol. 1, no. 4, pp. 4-25, 2013. 